\title{
PHYSIOLOGICAL RESPONSES OF WETLAND SPECIES RUMEX HYDROLAPATHUM TO INCREASED CONCENTRATION OF BIOGENOUS HEAVY METALS Zn AND Mn IN SUBSTRATE
}

\author{
Gederts levinsh ${ }^{1, \#}$, Elinna Dišlere ${ }^{1}$, Andis Karlsons ${ }^{2}$, Anita Osvalde ${ }^{2}$, \\ and Māra Vikmane ${ }^{1}$

\footnotetext{
${ }^{1}$ Faculty of Biology, University of Latvia, 1 Jelgavas Str., Rīga, LV-1004, LATVIA

2 Institute of Biology, University of Latvia, 3 Miera Str., Salaspils, LV-2169, LATVIA
} \\ \# Corresponding author, gederts.ievins@lu.Iv
}

Communicated by Māris Kḷaviṇš

\begin{abstract}
The aim of the present study was to determine if individuals of Rumex hydrolapathum Huds native to saline wetlands are able to tolerate high concentration of biogenous heavy metals $\mathrm{Zn}$ and $\mathrm{Mn}$ in substrate and to accumulate high concentration of these metals in aboveground parts. Plant physiological status was monitored by using non-destructive analysis of chlorophyll and chlorophyll a fluorescence. R. hydrolapathum plants accumulated up to $1840 \mathrm{mg} \cdot \mathrm{kg}^{-1} \mathrm{Zn}$ and $6400 \mathrm{mg} \cdot \mathrm{kg}^{-1} \mathrm{Mn}$ in older leaves. The usefulness of monitoring changes in chlorophyll concentration and chlorophyll a fluorescence parameters to predict physiological response of $\mathrm{R}$. hydrolapathum plants to excess $\mathrm{Zn}$ and $\mathrm{Mn}$ was not supported, as the lack of significant changes indicated that the model species showed adaptation to increased amount of metals in actively photosynthesizing tissues. It appears that $\mathrm{Zn}$ and $\mathrm{Mn}$ tolerance of $\mathrm{R}$. hydrolapathum is based primarily at the physiological level where metal accumulation in younger leaves and roots is restricted, and development of new leaves is promoted together with induction of senescence in older leaves that have accumulated the majority of $\mathrm{Zn}$ and $\mathrm{Mn}$. R. hydrolapathum can be characterised as a very promising model species for further studies for practical phytoremediation needs.
\end{abstract}

Key words: chlorophyll, chlorophyll a fluorescence, metal accumulation, phytoextraction potential, phytoremediation, toxicity.

\section{INTRODUCTION}

While wide use of more environment-friendly technologies has resulted in general improvement of environment quality, local soil pollution in industrial, urban and agricultural regions remains a challenging problem (Capra et al., 2014; Mitchell et al., 2014). In the case of heavy metals, phytoextraction is an environmentally friendly and cost-effective method of soil remediation, though requiring specific scientific knowledge for successful practical implementation (Guala et al., 2011; Yang et al., 2014). Choice of correct plant species to achieve a particular aim is of critical importance (Pinto et al., 2014). Desired characteristics of a selected plant species include tolerance to particular metals, capacity to accumulate target metals in plant shoots, ability to grow vigorously in particular conditions, large biomass etc.

Metal-tolerant plant species (metallophytes) can be either metal excluders or metal accumulators, through restriction of uptake in roots and/or translocation to shoots for the first type, and through mechanisms of detoxification in shoots for the second (Visioli and Marmiroli, 2013). In contrast to obligate metallophytes, which grow only in soils with a high concentration of particular metal ions, facultative metallophytes grow better in non-polluted soils but can survive even at extremely high substrate concentration of heavy metals.

A commonly used approach for species selection is to screen local plant populations growing on metalliferous 
soils to identify those with hyperaccumulation potential. So called metal hyperaccumulators are plants able to accummulate relatively high concentration of metals in shoots when growing in polluted soil, exceeding average values of non-accumulators by 10 to 500 times (Reeves et al., 2018). An important functional characteristic of hyperaccumulators is the ability to store most of the metal in aboveground parts (shoot to root concentration ratio or translocation factor $>1$ ) at a concentration higher than that in soil (shoot to soil concentration ratio or bioconcentration factor $>1$ ) (Buscaroli, 2017). Most hyperaccumulators as obligate metallophytes accumulate only one specific metal, making them useful only in the case of single metal contamination. In practice, however, many industry-, waste- and mining-related polluted soils contain several potentially harmful metals. Therefore, facultative metallophytes are promising candidates for phytoremediation studies.

For phytoextraction practice, it is necessary that plants are adapted to prevailing local climate conditions. In addition to hyperaccumulators, some species with average accumulation potential but with large biomass could be useful for phytoextraction. Recently, the phytoremediation potential of halophytes has gained interest due to common general characteristics of hyperaccumulators and salt-adapted plants (Lutts and Levèvre, 2015; Van Oosten and Maggio, 2015). In several families of flowering plants (Asteraceae, Amaranthaceae, Fabaceae, and Poaceae), metal hyperaccumulating and halophyte species are more closely related than if these two traits had evolved independently (Moray et al., 2016).

Several species of genus Rumex have been described as potential metal accumulators (Tang and Fang, 2001; Zhuang et al., 2007; Ye et al., 2012; Vondráčková et al., 2015). Rumex hydrolapathum Huds is a perennial species characteristic of wetlands. During studies of seasonal changes in leaf $\mathrm{Na}^{+}$ concentration in a number of species from a seawater affected coastal wetland, $R$. hydrolapathum appeared as a potential metal accumulator with functional characteristics useful for phytoremediation studies (Samsone and Ievinsh, 2018).

Both $\mathrm{Zn}$ and $\mathrm{Mn}$ are essential micronutrients in plants. Both $\mathrm{Zn}$ and $\mathrm{Mn}$ are structural components of many enzymes and regulatory proteins and are involved in several metabolic processes (Hacisalihoglu and Kochian, 2003; Anjum et al., 2015). The optimum concentration of $\mathrm{Zn}$ and $\mathrm{Mn}$ in soil for a majority of cultivated plants is 1 and $2 \mathrm{mg} \cdot \mathrm{l}^{-1}$, respectively (Osvalde, 2011), but most soils contain 10 to 300 $\mu \mathrm{g} \cdot \mathrm{kg}^{-1} \mathrm{Zn}$ and 450 to $4000 \mathrm{mg} \cdot \mathrm{kg}^{-1}$ of Mn (Anjum et al., 2015). The average concentration range in plant tissues for $\mathrm{Zn}$ is 15 to $150 \mathrm{mg} \cdot \mathrm{kg}^{-1}$ and that for $\mathrm{Mn} 1$ to $700 \mathrm{mg} \cdot \mathrm{kg}^{-1}$ (Visioli and Marmiroli, 2013). Zn toxicity usually appears above $300 \mathrm{mg} \cdot \mathrm{kg}^{-1}$ in leaves (Broadley et al., 2007). Symptoms of $\mathrm{Zn}$ toxicity include reduced growth (Wang et al., 2009), chlorosis of young leaves and necrosis (Santos et al., 2017), and impaired photosynthesis (Han et al., 2013). Mn toxicity normally appears at tissue Mn concentration above $200 \mathrm{mg} \cdot \mathrm{kg}^{-1}$, but this threshold concentration can vary sig- nificantly in a species-specific manner (Reichman, 2002). Elevated $\mathrm{Mn}$ is reported to decrease photosynthesis (Li et al., 2010), inhibit synthesis of chlorophyll (Clairmont et al., 1986) and reduce growth (Liu et al. 2010). Visual symptoms of Mn toxicity (chlorosis, brown necrotic spots) usually appear on older leaves (Elamin and Wilcox, 1986). According to the common criteria, the critical concentration in shoot tissues for hyperaccumulation of $\mathrm{Zn}$ and $\mathrm{Mn}$ is $1 \%$ or $10 \mathrm{~g} \cdot \mathrm{kg}^{-1}$ (Baker and Brooks, 1989). However, the critical threshold level for $\mathrm{Zn}$ has also been reported to be $3 \mathrm{~g} \cdot \mathrm{kg}^{-1}$ (Broadley et al., 2007). There are about 20 species known as $\mathrm{Zn}$ hyperaccumulators and 42 species as Mn hyperaccumulators (Reeves et al., 2017).

The aim of the present study was to determine if individuals of $R$. hydrolapathum native to saline wetlands are able (1) to tolerate high concentration of biogenous heavy metals $\mathrm{Zn}$ and $\mathrm{Mn}$ in substrate and (2) to accumulate high concentration of these metals in aboveground parts. Plant physiological status was monitored by using non-destructive analysis of chlorophyll and chlorophyll $a$ fluorescence. Most importantly, it was asked if $R$. hydrolapathum could be useful for practical phytoremediation purposes.

\section{MATERIALS AND METHODS}

Seeds of Rumex hydrolapathum Huds were collected at the beginning of September in a sea-affected wetland near Mērsrags, Latvia (Samsone and Ievinsh, 2018). After drying at room temperature for two weeks, the seeds were further kept at $4{ }^{\circ} \mathrm{C}$. For germination, seeds were imbibed in sterilized deionized water for $2 \mathrm{~h}$ and placed in plastic containers on autoclaved garden soil (Biolan, Finland) moistened with sterilised deionizsed water. The containers were placed in a plant growth cabinet MLR-352H (Sanyo Electric, Japan), photoperiod $16 \mathrm{~h}\left(40 \mu \mathrm{mol} \cdot \mathrm{m}^{-2} \cdot \mathrm{s}^{-1}\right)$, day/night temperature $20 / 15{ }^{\circ} \mathrm{C}$. Seedlings were transplanted to $200 \mathrm{ml}$ plastic containers filled with garden soil after appearance of the first two true leaves. The containers were placed in 481 plastic boxes closed with lids, placed in greenhouse and gradually adapted to greenhouse conditions. An experimental automated greenhouse (HortiMax, Netherlands) was used for the study. Supplemented light was provided by Master SON-TPIA Green Power CG T 400 W (Philips, Netherlands) and Powerstar HQI-BT 400 W/D PRO (Osram, Germany) lamps (380 $\mu \mathrm{mol} \cdot \mathrm{m}^{-2} \cdot \mathrm{s}^{-1}$ at the plant level), $16 \mathrm{~h}$ photoperiod. Day/night temperature was $23 / 15{ }^{\circ} \mathrm{C}$; relative air humidity was maintained at 60 to $70 \%$. When plants reached 5 to $10 \mathrm{~mm}$ height, they were transplanted to 1.21 plastic containers filled with 11 dry garden soil. Soil was moistened with deionised water. Substrate water content was monitored with a $\mathrm{HH} 2$ moisture meter equipped with a WET-2 sensor (Delta-T Devices, UK) and maintained at not less than $70 \%$ substrate water holding capacity throughout the experiment using deionised water. Individual containers were randomly placed on greenhouse bench and were repositioned twice a week. 
Plants were allowed to adapt for one week after transplanting and randomly distributed among seven treatment groups, five individual plants per treatment. Plants were exposed to increased metal concentrations over a time course of nine days in the form of three treatments with $\mathrm{ZnSO}_{4}$ or $\mathrm{MnSO}_{4}$, finally reaching respective metal concentration in substrate of $0.2,0.5$ and $1.0 \mathrm{~g} \cdot \mathrm{l}^{-1}$ for the respective metal ion. Analysis of photosynthesis-related parameters was started one day after the full treatment was performed (designated as week 1). On the second and fourth week, plants were fertilised with a Kristalon Green Label fertiliser (NPK 18-18-18 with micronutrients; Yara International, Norway) solubilised in deionised water $\left(150 \mathrm{~g} \cdot \mathrm{l}^{-1}\right)$, with $5 \mathrm{ml}$ of stock solution per $1,250 \mathrm{ml}$ of the final fertiliser per container.

Substrate electrical conductivity (EC) and $\mathrm{pH}$ were measured at the beginning of week 1 and at the end of week 4 . For EC, a HH2 moisture meter equipped with a WET-2 sensor (Delta-T Devices, UK) was used. Substrate pH was measured using a pH meter pH 3000 (STEP Systems, Germany). For every container, four separate measurements on all sides of the container were performed for both measurements.

In the middle of each week, photosynthesis-related parameters leaf chlorophyll concentration and chlorophyll $a$ fluorescence were measured for all individual plants of each treatment. Physiological analyses were performed on the physiologically most relevant actively photosynthesising leaf of each individual plant as determined by preliminary experiments. For this, the longest leaf of each individual plant was selected for measurement of photosynthesis-related parameters. Two separate readings were performed for each individual plant for both chlorophyll concentration measurement and chlorophyll $a$ fluorescence analysis. Chlorophyll concentration was measured by a chlorophyll meter CCM-300 (Opti-Sciences, USA). Chlorophyll $a$ fluorescence of leaves dark-adapted for at least 20 min was measured by Handy PEA fluorometer (Hansatech Instruments, UK). Chlorophyll $a$ fluorescence parameter Performance Index (total) was used for characterisation of photochemical activity. Performance Index is a complex indicator of photochemical efficiency combining three function-related (trapping of absorbed exciton, electron transport between the photosystems, reduction of end-electron acceptors) and structure-related (antenna chlorophyll per reaction centre chlorophyll) parameters (Strasser et al., 2000).

The experiment was terminated four weeks after the full treatment. On harvest, leaves were separated according to their age and position, as well as size, in old, middle, young and small leaves. The small leaves were located closer to the old leaves but likely originated from side shoots developing on the top of the main root. All types of leaves were counted and weighed separately. Plant roots were separated from substrate, carefully washed and weighed. Plant material was dried in a thermostat at $60{ }^{\circ} \mathrm{C}$ for $72 \mathrm{~h}$ and weighed to determine dry mass.
Dried plant tissue was used for chemical analysis. Tissue was ground in a A 11 basic analytical mill (IKA, Germany) to fine powder. A $1 \mathrm{~g}$ sample was weighed, dry-ashed in concentrated $\mathrm{HNO}_{3}$ vapour and dissolved in $\mathrm{HCl}$ : water (3 : 100). The concentrations of $\mathrm{Ca}, \mathrm{Mg}, \mathrm{Zn}$, and $\mathrm{Mn}$ were measured using an atomic absorption spectrophotometer (Perkin Elmer AAnalyst 700, acetylene-air flame). The K concentration was measured using a flame photometer (Jenwey PFP7, air-propane butane flame).

Statistical significance of differences between treatments was evaluated using the $t$ test using Prism (GraphPad Software, USA).

\section{RESULTS}

Treatment with increasing concentration of both $\mathrm{ZnSO}_{4}$ and $\mathrm{MnSO}_{4}$ resulted in similar linear increase of substrate EC (Fig. 1A). After four weeks of cultivation, EC decreased due to uptake of minerals, and the decrease was more pronounced for Mn treatment at high concentration (Fig. 1B). Application of both $\mathrm{ZnSO}_{4}$ and $\mathrm{MnSO}_{4}$ resulted in significant substrate acidification (Fig. 2A), but plant cultivation for four weeks resulted in further substrate acidification for Mn treatments (Fig. 2B).

Already four days after full treatment with both metals, the first visual symptoms of toxicity appeared on plant leaves. In the case of $\mathrm{Zn}$ treatment, they appeared as pink lesions on older leaves first in $1.0 \mathrm{~g} \cdot \mathrm{l}^{-1}$ treatment, developing in dry yellow, larger lesions (Fig. 3A). For $1.0 \mathrm{~g} \cdot \mathrm{l}^{-1}$ treatment with $\mathrm{Mn}$, reddish-brown interveinal lesions developed on older leaves (Fig. 3B). After 21 days, only occasional spots were seen on older leaves of plants treated with $0.2 \mathrm{~g} \cdot \mathrm{l}^{-1} \mathrm{Zn}$, leaves with dry yellow lesions were seen on $0.5 \mathrm{~g} \cdot 1^{-1}$ treated plants, and both necrotic leaves and leaves with dry yellow lesions were present on $1.0 \mathrm{~g} \cdot \mathrm{l}^{-1}$ treated plants (Fig. 3C). After 21 days, leaves of plants treated with Mn $0.2 \mathrm{~g} \cdot \mathrm{l}^{-1}$ remained unaffected, leaves with reddish-brown lesions were seen on $0.5 \mathrm{~g} \cdot \mathrm{l}^{-1}$ treated plants, and necrotising leaves with large dry lesions were present on plants treated with $1.0 \mathrm{~g} \cdot \mathrm{l}^{-1} \mathrm{Mn}$ (Fig. 3D).

Total fresh mass of leaves showed a decreasing tendency with increase of soil metal concentration for both $\mathrm{Zn}$ and $\mathrm{Mn}$, but this effect was statistically significant only at 1.0 $\mathrm{g} \cdot \mathrm{l}^{-1}$ for both $\mathrm{Zn}$ and $\mathrm{Mn}$, and $0.5 \mathrm{~g} \cdot \mathrm{l}^{-1}$ for $\mathrm{Zn}$ (Fig. 4A). In contrast, total dry mass of leaves did not change significantly (Fig. 4B). These differences might be due to treatment-induced stimulated desiccation of older leaves, as fresh mass decreased (Fig. 5A) while dry mass increased (Fig. 5B) with increasing concentration of metals. Changes in water content in old leaves further supported this relationship (Fig. 6A). In turn, water content in young leaves of plants treated with 0.5 and $1.0 \mathrm{~g} \cdot \mathrm{l}^{-1} \mathrm{Zn}$ significantly increased (Fig. 6B), which was related to significant decrease of dry mass of young leaves in these treatments (Fig. 7B). No significant changes were seen in respect to fresh mass of young leaves (Fig. 7A), as well as dry mass, in the case of 

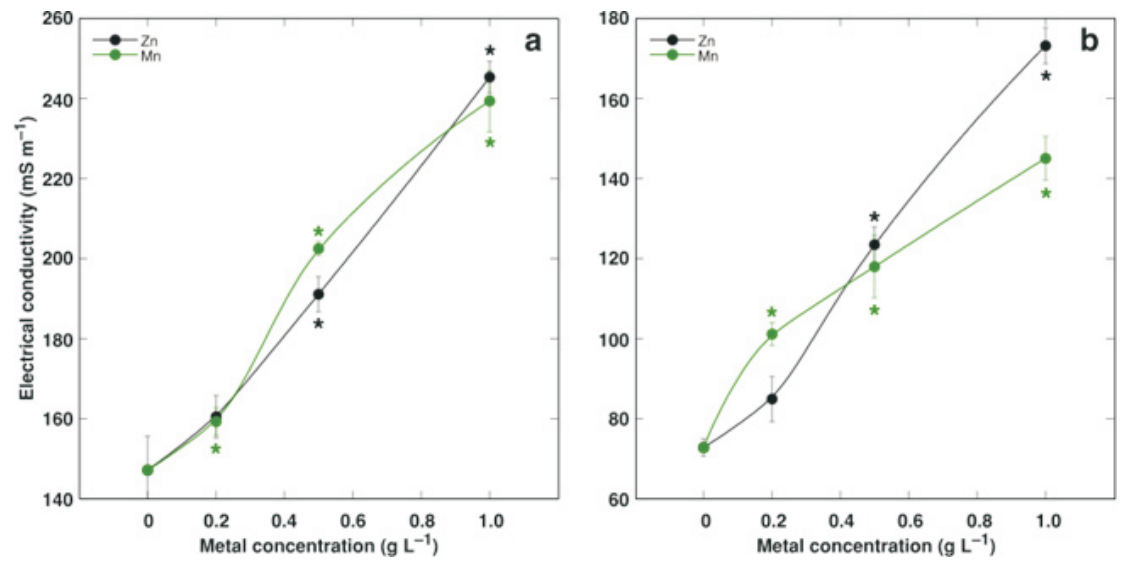

Fig. 1. Effect of treatment with different concentrations of $\mathrm{ZnSO}_{4}$ and $\mathrm{MnSO}_{4}$ on substrate electrical conductivity immediately after full treatment (A) and four weeks later (B) in containers with $R$. hydrolapathum plants. Data are means \pm SE from 5 replicates with 4 measurements each for each point. * indicates statistically significant difference from the respective control $(p<0.05)$.
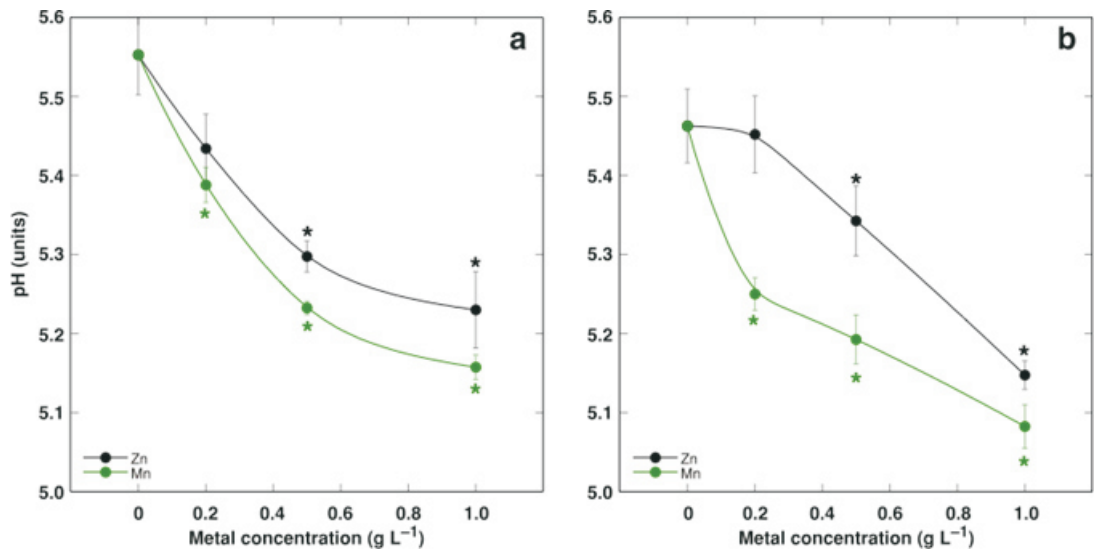

Fig. 2. Effect of treatment with different concentrations of $\mathrm{ZnSO}_{4}$ and $\mathrm{MnSO}_{4}$ on substrate $\mathrm{pH}$ immediately after full treatment (A) and four weeks later (B) in containers with $R$. hydrolapathum plants. Data are means \pm SE from 5 replicates with 4 measurements each for each point. * indicates statistically significant difference from the respective control $(p<0.05)$.
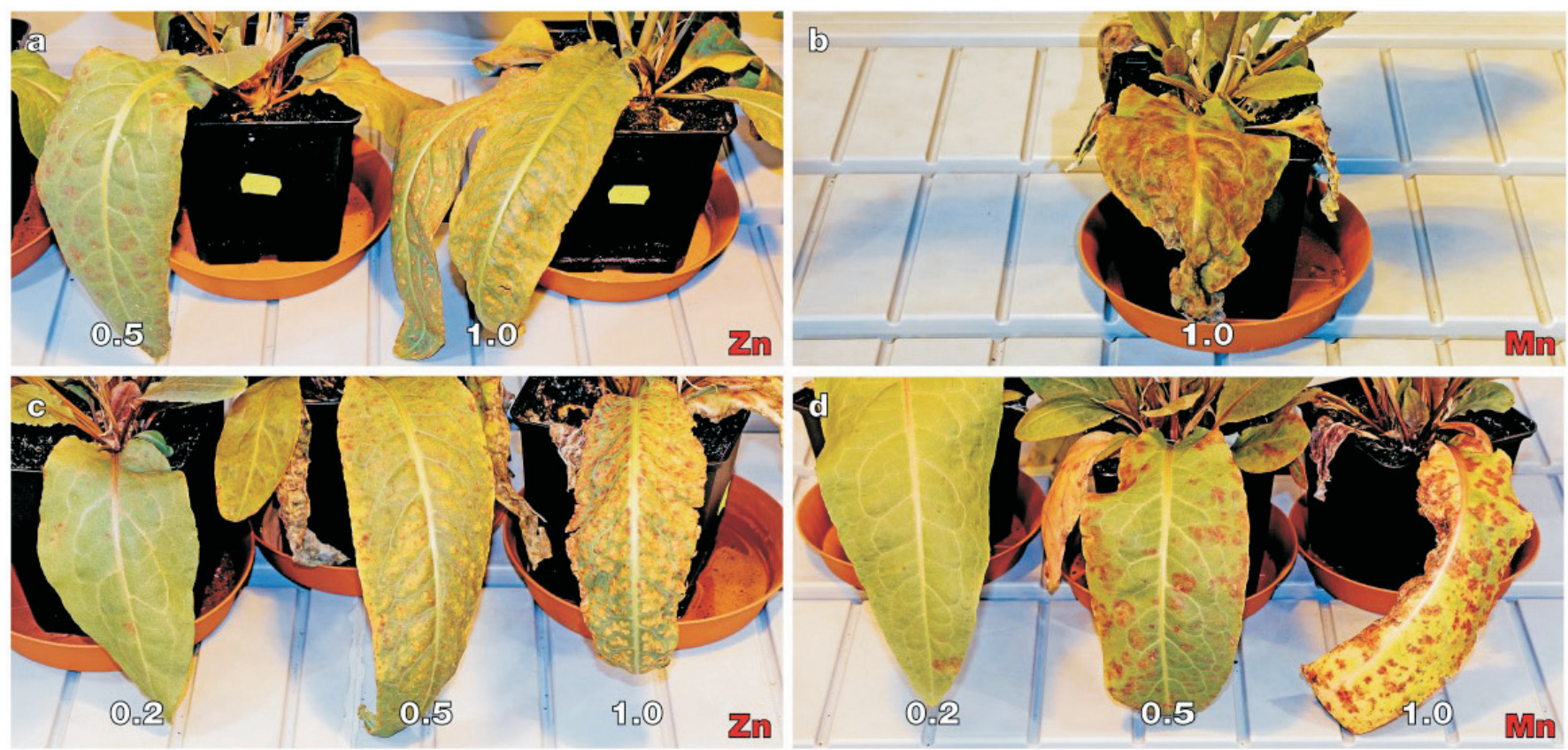

Fig. 3. Typical visual toxicity symptoms on leaves of $R$. hydrolapathum plants treated with $\mathrm{ZnSO}_{4}(\mathrm{~A}, \mathrm{C})$ and $\mathrm{MnSO}_{4}(\mathrm{~B}, \mathrm{D})$ four days after full treatment (A, B; week 1) and 21 days after full treatment (C, D; week 4).

Mn treatment (Fig. 7B). Total number of leaves showed some tendency to increase at increasing metal concentration, but the effect was statistically significant only for 1.0 g. $1^{-1} \mathrm{Zn}$ treatment (Fig. 8A). In contrast, the number of old leaves significantly increased in all treatments with $\mathrm{Zn}$ and $1.0 \mathrm{~g} \cdot \mathrm{l}^{-1}$ treatment with Mn (Fig. 8B).
Both fresh and dry mass of roots did not change significantly in Mn-treated plants, and linearly decreased in 0.5 and $1.0 \mathrm{~g} \cdot \mathrm{l}^{-1} \mathrm{Zn}$-treated plants (Fig. 9).

The photosynthesis-related indices (leaf chlorophyll concentration and chlorophyll $a$ fluorescence) were measured weekly in the largest, most actively photosynthesising leaf, 

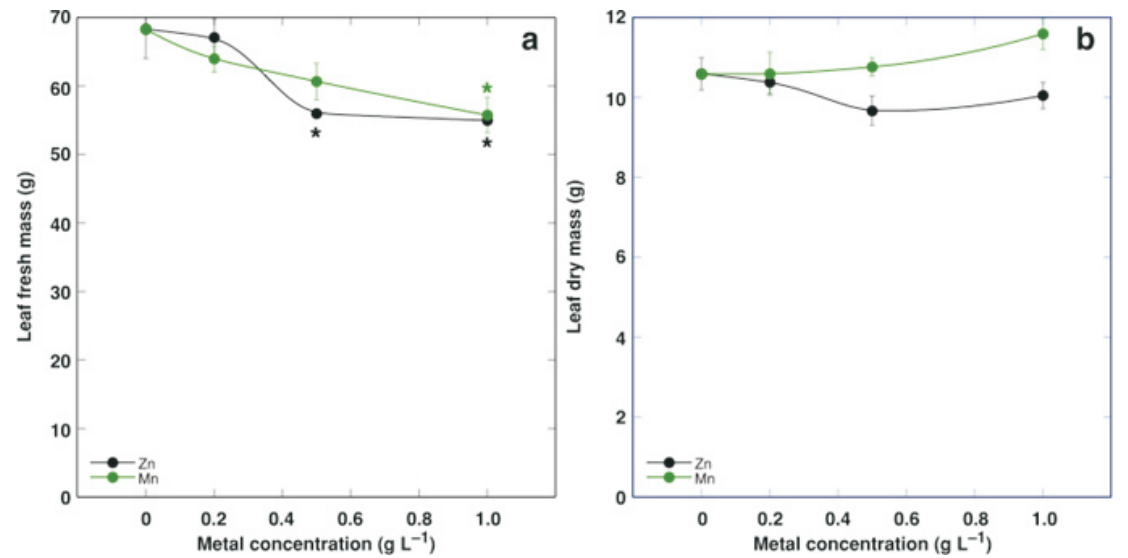

Fig. 4. Effect of treatment with different concentrations of $\mathrm{ZnSO}_{4}$ and $\mathrm{MnSO}_{4}$ on total fresh (A) and dry (B) mass of leaves of $R$. hydrolapathum. Data are means \pm SE from 5 replicates for each point. * indicates statistically significant difference from the respective control $(p<0.05)$.
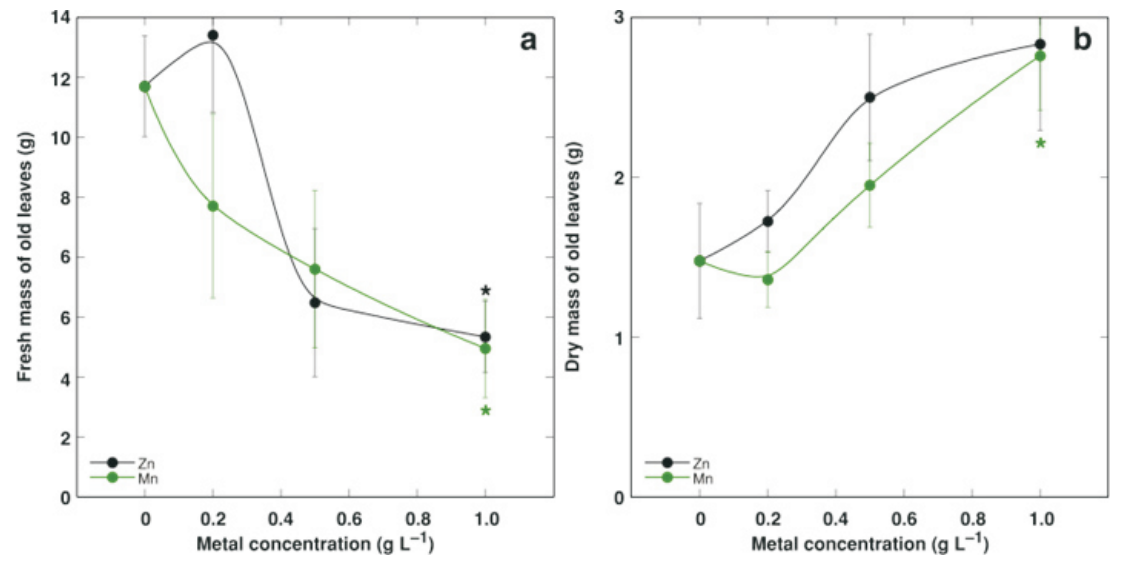

Fig. 5. Effect of treatment with different concentrations of $\mathrm{ZnSO}_{4}$ and $\mathrm{MnSO}_{4}$ on fresh (A) and dry (B) mass of old leaves of $R$. hydrolapathum. Data are means \pm SE from 5 replicates for each point. * indicates statistically significant difference from the respective control $(p<0.05)$.
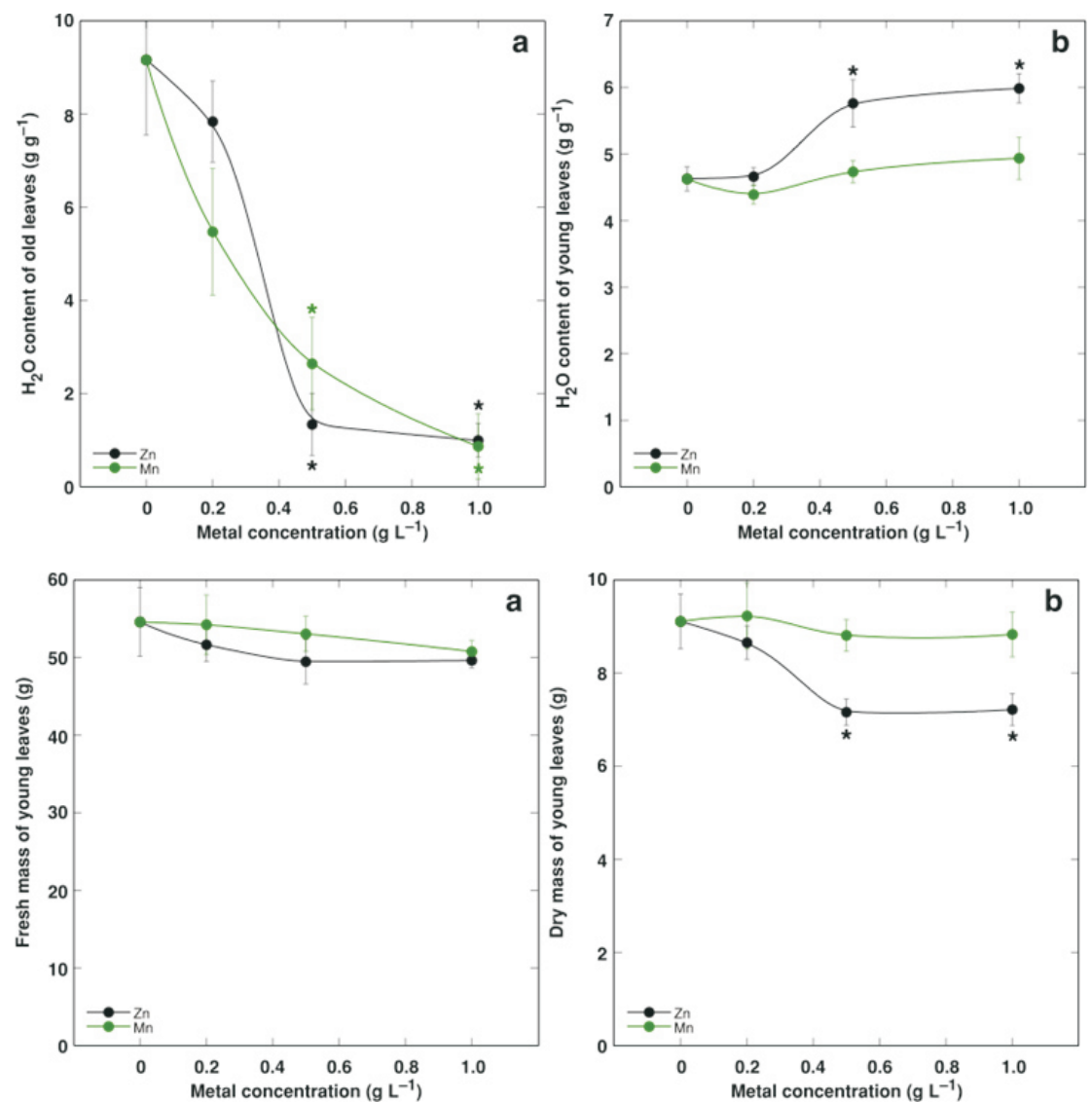

Fig. 6. Effect of treatment with different concentrations of $\mathrm{ZnSO}_{4}$ and $\mathrm{MnSO}_{4}$ on water content in old (A) and young (B) leaves of R. hydrolapathum. Data are means \pm SE from 5 replicates for each point. * indicates statistically significant difference from the respective control $(p<0.05)$.

Fig. 7. Effect of treatment with different concentrations of $\mathrm{ZnSO}_{4}$ and $\mathrm{MnSO}_{4}$ on fresh (A) and dry (B) mass of young leaves of $R$. hydrolapathum. Data are means \pm SE from 5 replicates for each point. * indicates statistically significant difference from the respective control $(p<0.05)$.

and therefore any recorded changes in metal-treated plants reflected overall physiological status of the plant rather than particular toxic effect. Changes in leaf chlorophyll concentration were relatively small and were slightly negatively af- fected by all treatments except $0.2 \mathrm{~g} \cdot \mathrm{l}^{-1} \mathrm{Zn} 2$ and 3 weeks after full treatment (Fig. 10A). An increasing trend of chlorophyll concentration was evident for Mn-treated plants, especially, at $0.5 \mathrm{~g} \cdot \mathrm{l}^{-1}$. The chlorophyll $a$ fluorescence param- 

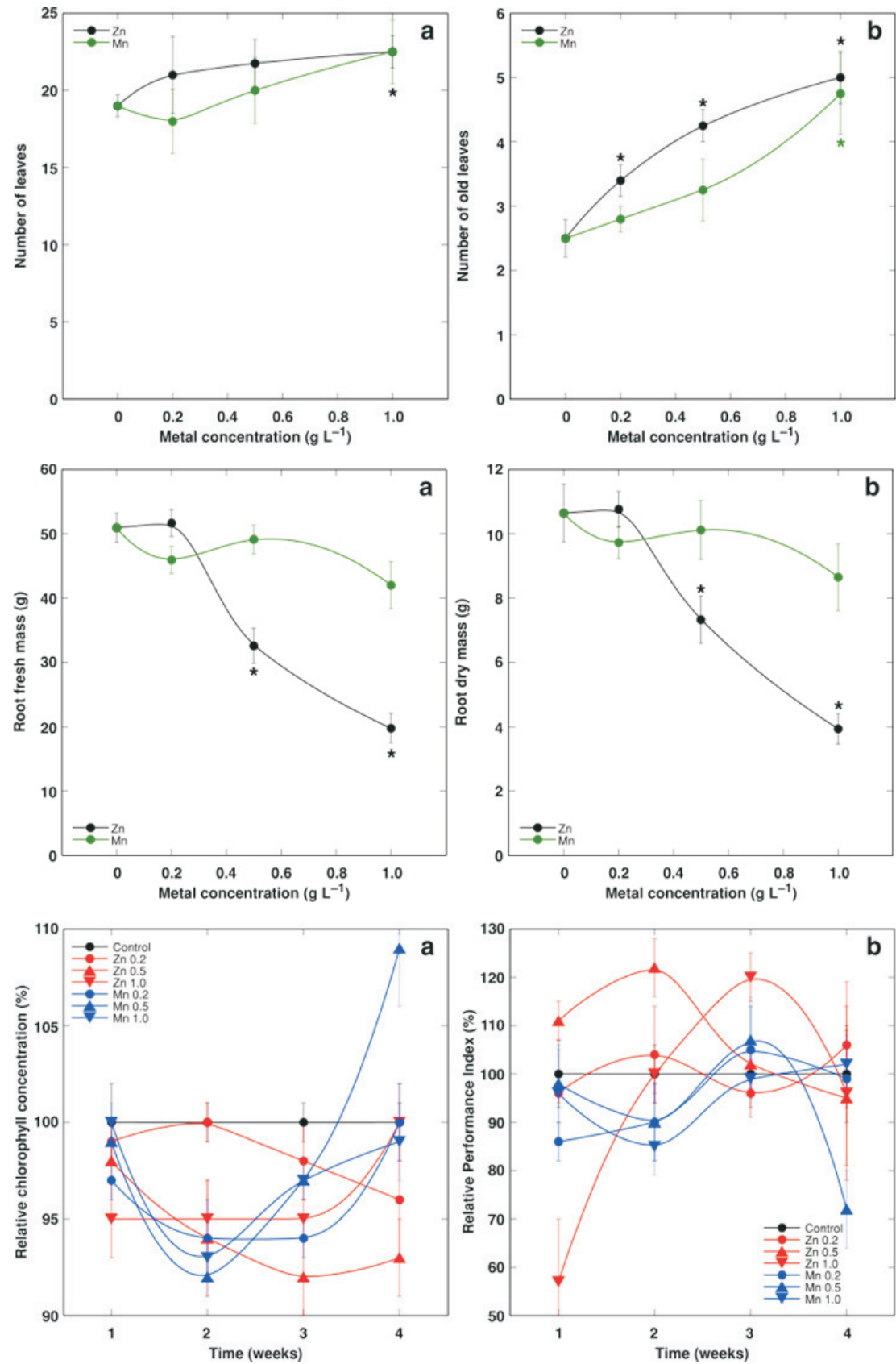

Fig. 8. Effect of treatment with different concentrations of $\mathrm{ZnSO}_{4}$ and $\mathrm{MnSO}_{4}$ on the total number of leaves (A) and number of old leaves (B) of $R$. hydrolapathum. Data are means \pm SE from 5 replicates for each point. * indicates statistically significant difference from the respective control $(p<$ $0.05)$.

Fig. 9. Effect of treatment with different concentrations of $\mathrm{ZnSO}_{4}$ and $\mathrm{MnSO}_{4}$ on fresh (A) and dry (B) mass of roots of $R$. hydrolapathum. Data are means \pm SE from 5 replicates for each point. * indicates statistically significant difference from the respective control $(p<0.05)$.

Fig. 10. Effect of treatment with different concentrations of $\mathrm{ZnSO}_{4}$ and $\mathrm{MnSO}_{4}$ on changes in relative chlorophyll concentration (A) and Performance Index (B) in leaves of $R$. hydrolapathum. Data are means $\pm \mathrm{SE}$ from 5 replicates, each with 2 measurements, for each point. eter Performance Index was relatively more affected by treatments, but no general trend of changes was evident (Fig. 10B). Initially (week 1), the Performance Index was significantly lower in $\mathrm{Zn}$-treated plants at $1.0 \mathrm{~g} \cdot \mathrm{l}^{-1}$, but it recovered and on week 3 was even above the control level. In contrast, Zn-treated plants at $0.5 \mathrm{~g} \cdot \mathrm{l}^{-1}$ showed initial increase of the Performance Index (week 1 and 2). Changes were less evident for Mn-treated plants, except some decrease in the Performance Index at week 2 at all concentrations.

In $\mathrm{Zn}$ - and Mn-treated $R$. hydrolapathum plants, $\mathrm{Zn}$ and $\mathrm{Mn}$ concentration in tissues increased with increasing substrate metal concentration (Fig. 11). Zn preferentially accumulated in older leaves and was at a relatively low level in roots and young leaves (Fig. 11A). Maximum $\mathrm{Zn}$ concentration achieved was $1840 \mathrm{mg} \cdot \mathrm{kg}^{-1}$. Similar concentration of Mn accumulated in old, middle and small leaves, but it was significantly lower in young leaves, and relatively very low in roots (Fig. 11B). Maximum Mn concentration was 6400 $\mathrm{mg} \cdot \mathrm{kg}^{-1}$. The total amount of both metals in the whole plant increased linearly with increasing metal concentration in substrate (Fig. 12). Old leaves and middle leaves together accumulated the largest amount of $\mathrm{Zn}$, but for $\mathrm{Mn}$ the contribution of leaves decreased in the order middle leaves $>$ old leaves $>$ small leaves $>$ young leaves.

The ability to accumulate metals preferentially in shoots was characterised by the translocation factor (TF). In different parts of control plants, TF for $\mathrm{Zn}$ was within the range of 1.11 to 1.35 and for Mn was 1.81 to 5.6 (Table 1). TF increased in old, middle and small leaves with increasing $\mathrm{Zn}$ concentration in substrate but decreased in young leaves. In Mn-treated plants, TF increased in all leaves with increasing metal concentration in substrate. 

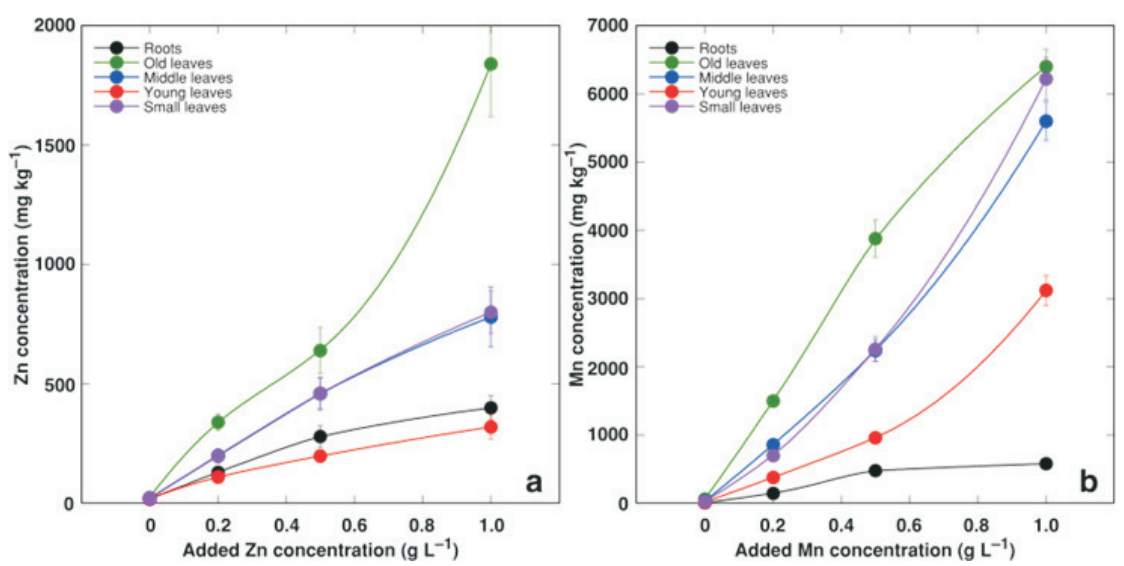

Fig. 11. Effect of treatment with different concentrations of $\mathrm{ZnSO}_{4}$ on concentration of $\mathrm{Zn}(\mathrm{A})$ and $\mathrm{MnSO}_{4}$ on concentration of $\mathrm{Mn}$ (B) in different parts of $R$. hydrolapathum. Data are means $\pm \mathrm{SE}$ from 3 replicates for each point.
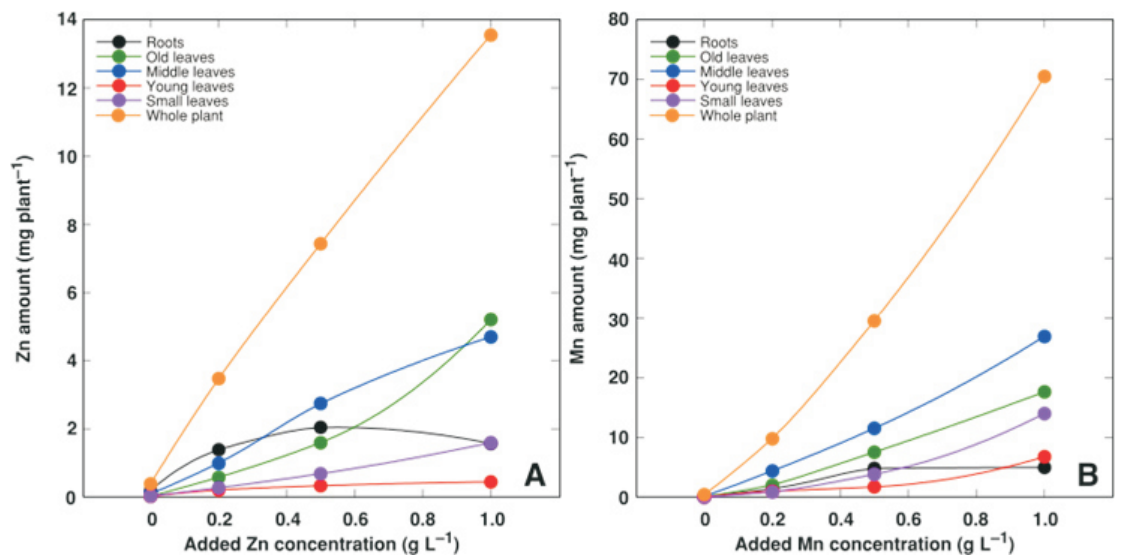

Fig. 12. Effect of treatment with different concentrations of $\mathrm{ZnSO}_{4}$ on total amount of $\mathrm{Zn}(\mathrm{A})$ and $\mathrm{MnSO}_{4}$ on total amount of $\mathrm{Mn}(\mathrm{B})$ in different parts and whole plants of $R$. hydrolapathum. Data are means \pm SE from 3 replicates for each point.

Table 1. Root-to-shoot translocation factors for different concentrations of $\mathrm{Zn}$ and $\mathrm{Mn}$ in various leaves of $R$. hydrolapathum

\begin{tabular}{l|c|c|c|c|c}
\hline Metal & $\begin{array}{c}\text { Concentration } \\
\left(\mathrm{g} \cdot \mathrm{l}^{-1}\right)\end{array}$ & $\begin{array}{c}\text { Old } \\
\text { leaves }\end{array}$ & $\begin{array}{c}\text { Small } \\
\text { leaves }\end{array}$ & $\begin{array}{c}\text { Middle } \\
\text { leaves }\end{array}$ & $\begin{array}{c}\text { Young } \\
\text { leaves }\end{array}$ \\
\hline $\mathrm{Zn}$ & 0 & 1.35 & 1.24 & 1.12 & 1.11 \\
& 0.2 & 2.6 & 1.52 & 1.54 & 0.85 \\
& 0.5 & 2.29 & 1.64 & 1.64 & 0.71 \\
$\mathrm{Mn}$ & 1.0 & 4.6 & 2.0 & 1.95 & 0.80 \\
& 0 & 5.6 & 2.73 & 2.91 & 1.81 \\
& 0.2 & 10.14 & 4.73 & 5.81 & 2.57 \\
& 0.5 & 8.08 & 4.71 & 4.67 & 2.00 \\
& 1.0 & 11.00 & 10.70 & 9.66 & 5.38
\end{tabular}

Treatment with $\mathrm{Zn}$ significantly decreased $\mathrm{Mn}$ concentration in old, middle and small leaves at all concentrations, but in young leaves only at $0.2 \mathrm{~g} \cdot \mathrm{l}^{-1}$ (Fig. 13A). In contrast, $\mathrm{Mn}$ treatment tended to increase tissue $\mathrm{Zn}$ concentration, and the effect in leaves was significant for the $1.0 \mathrm{~g} \cdot \mathrm{l}^{-1}$ treatment, but in roots it was significant at 0.5 and $1.0 \mathrm{~g} \cdot \mathrm{l}^{-1}$ (Fig. 13B). In control plants, concentration of $\mathrm{K}$ significantly differed between different parts, decreasing in the order old leaves $>$ young leaves $>$ small leaves $>$ middle leaves $>$ roots (Fig. 14). Zn treatment significantly increased $\mathrm{K}$ concentration in all parts in the $1.0 \mathrm{~g} \cdot \mathrm{l}^{-1}$ treatment, but in the $0.5 \mathrm{~g} \cdot \mathrm{l}^{-1}$ treatment also in younger leaves (Fig. 14A). In contrast, Mn treatment resulted in lower K concentration in several treatments in old, young and small leaves, but for $0.2 \mathrm{~g} \cdot \mathrm{l}^{-1}$ there was an increase in $\mathrm{K}$ concentration in old leaves (Fig. 14B). Distribution of Ca (Fig. 15) and $\mathrm{Mg}$ (Fig. 16) in different parts of control plants was similar, with highest concentration in old leaves, decreasing in middle and small leaves, and further in young leaves and roots. $\mathrm{Zn}$ treatment resulted in decrease of both $\mathrm{Ca}$ and $\mathrm{Mg}$ in old leaves, and the effect was significant at 0.5 and
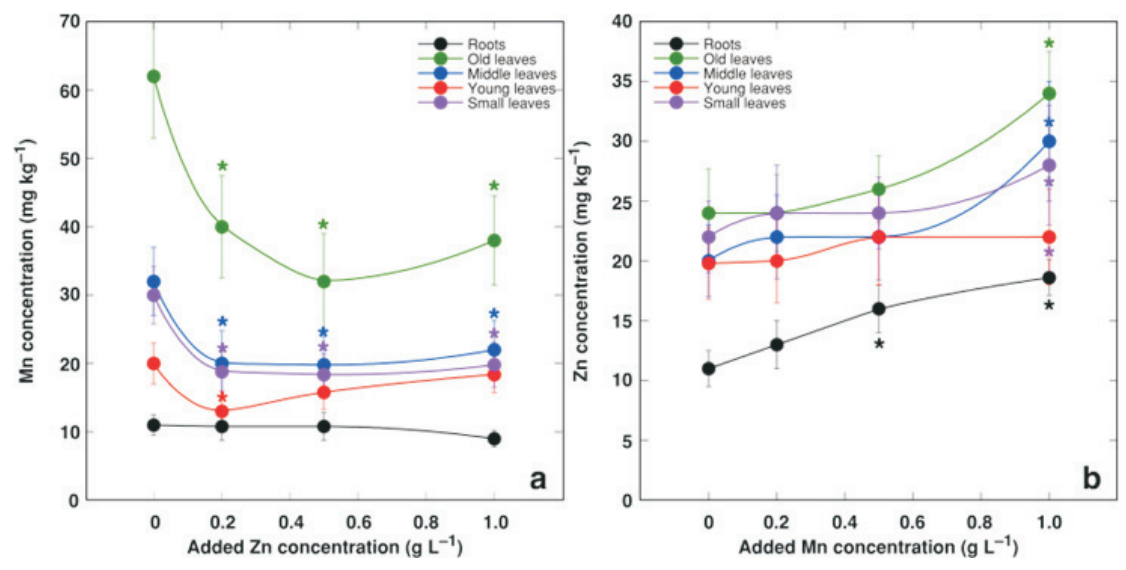

Fig. 13. Effect of treatment with different concentrations of $\mathrm{ZnSO}_{4}$ on concentration of $\mathrm{Mn}(\mathrm{A})$ and $\mathrm{MnSO}_{4}$ on concentration of $\mathrm{Zn}$ (B) in different parts of $R$. hydrolapathum. Data are means $\pm \mathrm{SE}$ from 3 replicates for each point. * indicates statistically significant difference from the respective control $(p<0.05)$. 

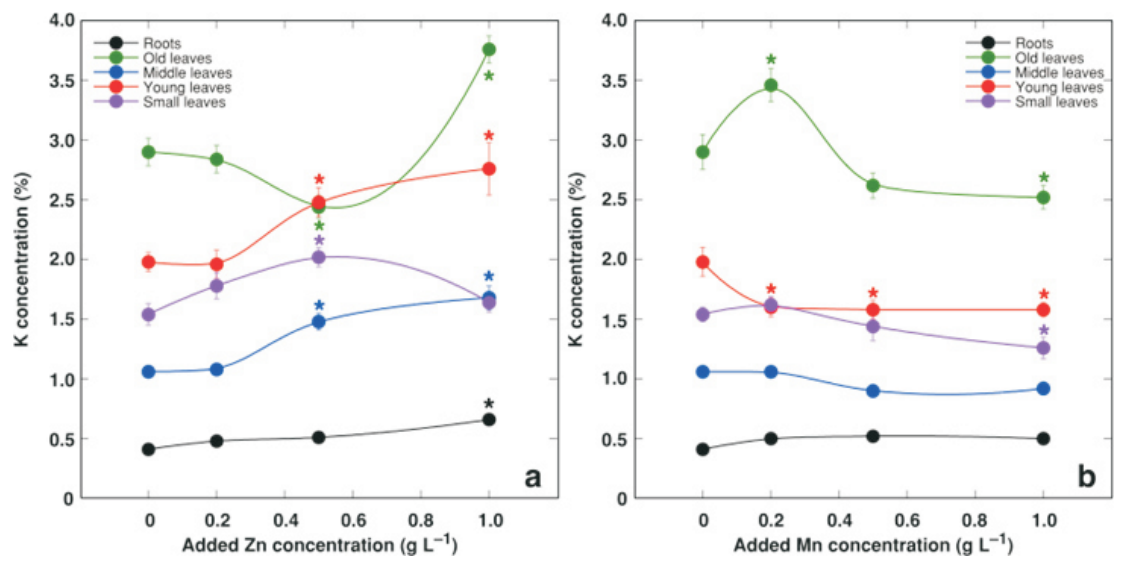

Fig. 14. Effect of treatment with different concentrations of $\mathrm{ZnSO}_{4}(\mathrm{~A})$ and $\mathrm{MnSO}_{4}$ (B) on concentration of $\mathrm{K}$ in different parts of $R$. hydrolapathum. Data are means \pm SE from 3 replicates for each point. * indicates statistically significant difference from the respective control $(p<0.05)$.
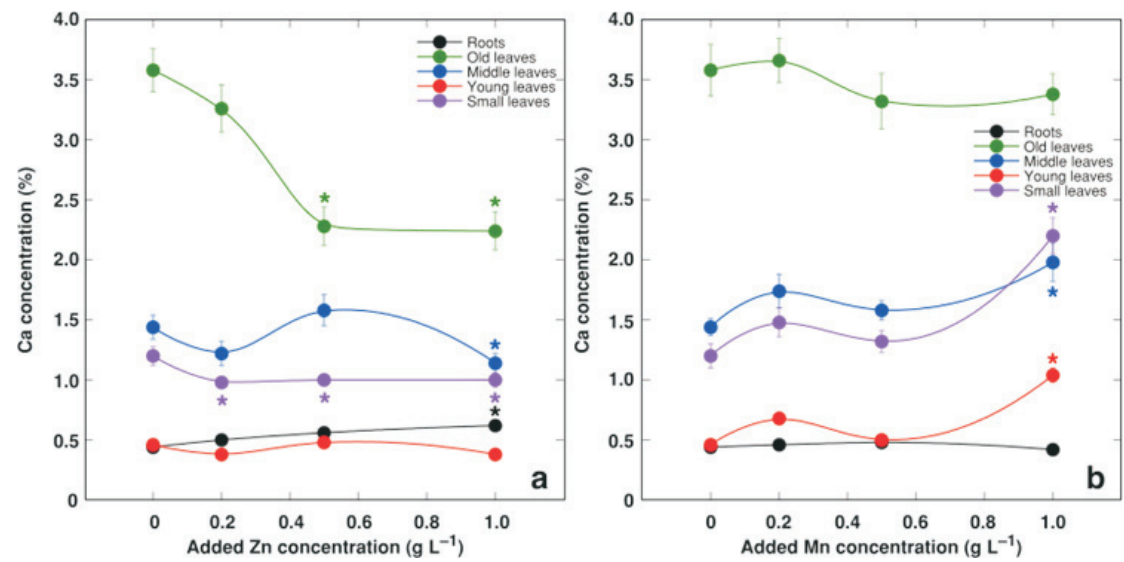

Fig. 15. Effect of treatment with different concentrations of $\mathrm{ZnSO}_{4}$ (A) and $\mathrm{MnSO}_{4}$ (B) on concentration of $\mathrm{Ca}$ in different parts of $R$. hydrolapathum. Data are means \pm SE from 3 replicates for each point. * indicates statistically significant difference from the respective control $(p<0.05)$.
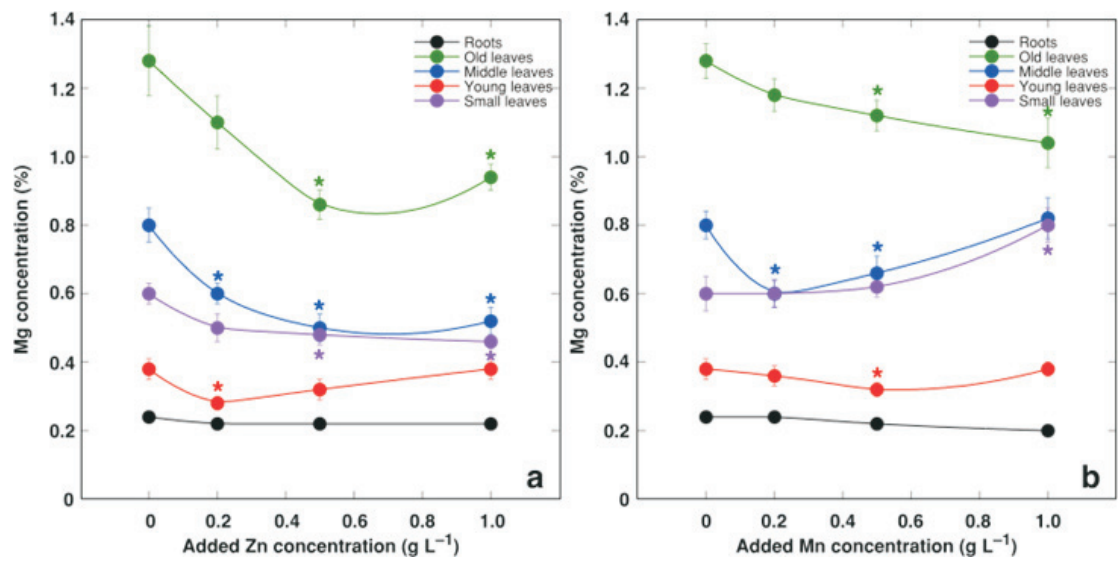

Fig. 16. Effect of treatment with different concentrations of $\mathrm{ZnSO}_{4}$ (A) and $\mathrm{MnSO}_{4}$ (B) on concentration of $\mathrm{Mg}$ in different parts of R. hydrolapathum. Data are means \pm SE from 3 replicates for each point. $*$ indicates statistically significant difference from the respective control $(p<0.05)$.

$1.0 \mathrm{~g} \cdot \mathrm{l}^{-1}$. Similarly, there was a tendency for decrease in $\mathrm{Ca}$ and $\mathrm{Mg}$ also in middle and small leaves of $\mathrm{Zn}$-treated plants, but the effect was not always statistically significant. $\mathrm{Mn}$ treatment significantly increased $\mathrm{Ca}$ concentration in middle, small and young leaves at $1.0 \mathrm{~g} \cdot \mathrm{l}^{-1}$ (Fig. 15B), but the effect of $\mathrm{Mn}$ treatment on $\mathrm{Mg}$ concentration was rather controversial, it increased in middle and small leaves, but decreased in old leaves (Fig. 16B).

\section{DISCUSSION}

The present study was based on the assumption that not only hyperaccumulators as obligate metallophytes, but also metal-tolerant accumulator species with good accumulation potential and high biomass production are promising candidates for phytoextraction purposes (Broadhurst et al., 2015). Within the last decade, there has been a large interest in the use of halophytic plant species as heavy metal hyperaccumulators (Liang et al., 2017). Experimental evidence has built up showing that salt tolerance and metal hyperaccumulation may be physiologically and evolutionary associated (Moray et al., 2016). It seems that these traits are associated with common morphological and biochemical mechanisms: the ability to tightly regulate ion transport and sequestration, capacity to maintain osmotic balance, an efficient cellular antioxidative system, plasticity to switch appropriate developmental programmes, etc. (Sruthi et al., 2017). So far, mostly obligate halophytes species from arid habitats have been used in phytoextraction studies (Hamed et al., 2013). In the present study with $R$. hydrolapathum, the model species used was identified as a potential metal accumulator during whole-season screening of vegetation on a sea-affected wetland for a $\mathrm{Na}^{+}$accumulation potential (Samsone and Ievinsh, 2018). 
In general, wetland plants are highly tolerant to toxic elements and have good capacity for phytoremediation (Yang and Ye, 2009). This is because wetlands form an interface between land and water basins leading to accumulation of wastewaters containing heavy metals (Gao et al., 2016). For example, in a polluted natural wetland with high sediment concentration of several metals, including $\mathrm{Zn}\left(368 \mathrm{mg} \cdot \mathrm{kg}^{-1}\right)$ and $\mathrm{Mn}\left(1044 \mathrm{mg} \cdot \mathrm{kg}^{-1}\right)$, maximum concentration of both elements was achieved in roots of Phragmites australis (135 and $438 \mathrm{mg} \cdot \mathrm{kg}^{-1}$, respectively), with significantly lower concentration in leaves (67 and $367 \mathrm{mg} \cdot \mathrm{kg}^{-1}$ ) (Bonanno et al., 2018).

The present study was relatively short-term (only four weeks after reaching final concentrations) and involved acute treatment with extremely high concentrations of $\mathrm{Zn}$ and $\mathrm{Mn}$; therefore, it is difficult to compare the obtained results with those from other studies. However, the results indicated that $R$. hydrolapathum plants are relatively tolerant to elevated content of both $\mathrm{Zn}$ and $\mathrm{Mn}$ in substrate and have good metal accumulation potential.

It is usually argued that hyperaccumulating plants should not show signs of phytotoxicity (Rascio and Navari-Izzo, 2011). However, assessment of phytotoxicity is based on several criteria, including (1) appearance of visual injury-related symptoms, (2) retardation of growth and development, (3) accumulation of toxic substance in plant tissues, and (4) presence of biochemical mechanisms related to toxicity (Naidu et al., 2003). Thus, phytotoxicity is a complex problem. However, visual symptoms and growth impairment under effect of $\mathrm{Mn}$ and $\mathrm{Zn}$ appear even for hyperaccumulators. Toxicity symptoms for the Mn hyperaccumulator Celosia argentea were observed to appear at relatively low Mn concentration in a hydroponic system: stem, root and leaf biomass decreased above $0.1 \mathrm{~g} \cdot \mathrm{l}^{-1}$, and leaf necrosis was observed at $0.6 \mathrm{~g} \cdot \mathrm{l}^{-1}$ already after four days (Liu et al., 2014). $\mathrm{Zn}$ hyperaccumulators Thlaspi caerulescens and Arabidopsis halleri both displayed symptoms of phytotoxicity at $1000 \mu \mathrm{M} \mathrm{Zn}\left(65 \mathrm{mg} \cdot \mathrm{l}^{-1}\right)$ in conditions of hydroponics (Shen et al., 1997; Jin et al., 2008). In contrast, in the present study, visual symptoms of toxicity appeared at $0.5 \mathrm{~g} \cdot \mathrm{l}^{-1}$ for both $\mathrm{Zn}$ and $\mathrm{Mn}$, but shoot growth of $R$. hydrolapathum was not negatively affected even at $1.0 \mathrm{~g} \cdot \mathrm{l}^{-1}$ (Fig. 4). Root growth was negatively affected only by 0.5 and $1.0 \mathrm{~g} \cdot \mathrm{l}^{-1}$ $\mathrm{Zn}$, but not by any concentration of Mn (Fig. 9). Indeed, inhibition of root growth is a typical physiological characteristic of Zn toxicity (Ren et al., 1993). While clear toxicity symptoms appeared on older leaves of both $\mathrm{Zn}$ - and Mn-treated plants at 0.5 and $1.0 \mathrm{~g} \cdot \mathrm{l}^{-1}$ concentration, $R$. hydrolapathum plants were able to maintain vigorous growth by accumulating excess metals in older leaves and by initiating programmed senescence and stimulation of development of new leaves.

At optimum supply level, $\mathrm{Zn}$ as a mobile element accumulates in growing tissues, e.g. young leaves, but its concentration usually decreases in older leaves (Longnecker and Robson, 1993). In contrast, mobility of $\mathrm{Mn}$ in phloem is rather low, and therefore, toxicity symptoms first appear on older leaves (Loneragan, 1988). While these element mobility-related principles were supported for Mn-treated plants, Zn-treated plants showed a metal accumulation pattern contradicting these principles. Usually old leaves accumulate lower concentration of $\mathrm{Zn}$ in comparison to younger leaves (Gupta et al., 2016), but this was not the case in $R$. hydrolapathum, as identical concentration of $\mathrm{Zn}$ accumulated in different leaves of control plants (Fig. 13B), while in $\mathrm{Zn}$-treated plants, $\mathrm{Zn}$ concentration decreased from older to middle leaves and further to young leaves (Fig. 11A). It seems that $\mathrm{Zn}$ distribution in $R$. hydrolapathum is specifically regulated to exclude the element from growing leaves. Since the largest part of the accumulated $\mathrm{Zn}$ is found in cell vacuoles, lower concentration of $\mathrm{Zn}$ in young leaves has been associated with lower degree of vacuolization in mesophyll cells of growing leaves (Küpper et al., 1999).

According to the common criteria (Broadley et al., 2007), with maximum accumulation of $1840 \mathrm{mg} \cdot \mathrm{kg}^{-1} \mathrm{Zn}$ and 6400 $\mathrm{mg} \cdot \mathrm{kg}^{-1} \mathrm{Mn}$ in leaves of $R$. hydrolapathum, this species cannot be designated as a metal hyperaccumulator. However, the potential accumulation of $R$. hydrolapathum was relatively high, especially given the high values of translocation factors found (Table 1). For comparison, in natural contaminated soil containing $6172 \mathrm{mg} \cdot \mathrm{kg}^{-1} \mathrm{Zn}$ and 2688 $\mathrm{mg} \cdot \mathrm{kg}^{-1} \mathrm{Mn}$, Rumex obtusifolius plants accumulated 1260 $\mathrm{mg} \cdot \mathrm{kg}^{-1} \mathrm{Zn}$ and $183 \mathrm{mg} \cdot \mathrm{kg}^{-1} \mathrm{Mn}$ in leaves, giving respective translocation factors 1 , which clearly indicated an exclusion strategy (Vondráčková et al., 2014). In another species of the genus, Rumex acetosa from a Zn-polluted mine heap accumulated about seven-fold less $\mathrm{Zn}$ in leaves, in comparison to the adjacent typical accumulator plant Noccaea caerulescens (Bothe and Słomka, 2017).

Preferential accumulation of metal ions in leaves in comparison to roots is a typical characteristic of hyperaccumulators (Masarovičová et al., 2010). For example, a hyperaccumulating ecotype of Sedum alfredii had a translocation factor for $\mathrm{Zn} 4.7$ to 5.7, while a non-hyperaccumulating ecotype of $S$. alfredii had a translocation factor of only 0.10 to 0.17 (Li et al., 2006). However, the $\mathrm{Zn}$ hyperaccumulator Arabis paniculata accumulated a maximum concentration of 6.0 and $12.9 \mathrm{~g} \cdot \mathrm{kg}^{-1} \mathrm{Zn}$ in shoots and roots, respectively, when cultivated at $0.07 \mathrm{~g} \cdot \mathrm{L}^{-1} \mathrm{Zn}$ for three weeks in hydroponics in a mixture of sand and vermiculite (Zeng et al., 2011). The same species accumulated $20.8 \mathrm{~g} \cdot \mathrm{kg}^{-1} \mathrm{Zn}$ in shoots when growing in a mining soil containing $17.9 \% \mathrm{Zn}$ (Tang et al., 2009). Typical Mn hyperaccumulator plants accumulate higher concentration of $\mathrm{Mn}$ in shoots in comparison to roots, irrespective of external Mn concentration (Xue et al., 2004). In the present study, metals were excluded from roots and young growing leaves of $R$. hydrolapathum, and the exclusion potential was significantly higher for $\mathrm{Zn}$ in comparison to $\mathrm{Mn}$. In young leaves of $\mathrm{Zn}$-treated $R$. hydrolapathum plants, concentration of $\mathrm{Zn}$ was even lower than that in roots, which is rather striking given the high mobility of $\mathrm{Zn}$ (Longnecker and Robson, 1993). In our study, Zn concentration in control plants did not depend on leaf developmental stage/age (Fig. 13B), in contrast to that 
for Mn (Fig. 13A). The translocation factor increased with increasing soil metal concentration for Mn for all types of leaves, but for $\mathrm{Zn}$ it decreased in young leaves, further supporting $\mathrm{Zn}$ exclusion from growing tissues (Table 1). In general, the translocation factor for Mn was significantly higher and exceeded 10 in older leaves.

The total amount of Mn attained in the present study was 70 $\mathrm{mg}$ per plant only after four weeks at $1.0 \mathrm{~g} \cdot \mathrm{l}^{-1} \mathrm{Mn}$ (Fig. 12B). In comparison, hyperaccumulator species Phytolacca acinosa accumulated up to $259 \mathrm{mg} \mathrm{Mn}$ per plant when grown in hydroponics in the presence of $0.2 \mathrm{~g} \cdot \mathrm{l}^{-1} \mathrm{Mn}$ for 45 days (Xue et al., 2004). The amount of Zn per plant was even lower. Thus, it may seem that accumulating potential of $R$. hydrolapathum for both $\mathrm{Zn}$ and $\mathrm{Mn}$ is relatively low. However, the accumulating ability can be greatly enhanced by means of different agrotechnical measures and addition of chemical modificators, as already shown for different hyperaccumulating plant species (Pinto et al., 2014). In addition, the typical $\mathrm{Zn}$ hyperaccumulating species Arabidopsis halleri and Noccaea caerulescens are not very useful for practical phytoextraction needs because of the relatively small size of individuals (Liang et al., 2009). R. hydrolapathum had a high growth rate, accumulated high biomass, and was able to replace old leaves. This type of developmental plasticity has been described for several halophyte and metal hyperaccumulator species, where metal ions are directed to older leaves with further switch to programmed organ senescence (Albert, 1975; Boyd, 2004). As the particular accession of $R$. hydrolapathum was found in a naturally salt-affected wetland, it would be interesting to further explore effect of $\mathrm{NaCl}$ on tolerance against and accumulation of $\mathrm{Zn}$ and $\mathrm{Mn}$ in these plants. Indeed, for a salt marsh species Kosteletzkya virginica, addition of $\mathrm{NaCl}$ diminished deleterious effects of $\mathrm{Zn}$ treatment on growth and modified $\mathrm{Zn}$ distribution, resulting in accumulation of more metal in the older leaves (Han et al., 2013).

One of the most important physiological changes due to excess of $\mathrm{Zn}$ is related to its effect on mineral nutrition. In general, concentration of essential nutrients in tissues is decreased as a result of $\mathrm{Zn}$ toxicity (Anjum et al., 2015). Also, high $\mathrm{Mn}$ treatment increased $\mathrm{K}$ and $\mathrm{Zn}$ accumulation and decreased that of $\mathrm{Mg}$ only in roots but not in shoots of soybean (Santos et al., 2017). An important point to consider in experiments with $\mathrm{Zn}$ and $\mathrm{Mn}$ treatment in soil is related to the fact that application of respective sulphate salts at high concentration can influence soil $\mathrm{pH}$, which further can affect mineral uptake. Application of increasing concentration of $\mathrm{ZnSO}_{4}$ up to $1000 \mathrm{mg} \cdot \mathrm{kg}^{-1}$ decreased soil $\mathrm{pH}$ from 5.9 to 5.2 in an experiment with red clover (Li and Christie, 2001). Decrease in soil $\mathrm{pH}$ leads to increase in soluble fraction of $\mathrm{Zn}$, making it more available (Wang et al., 2006). In the present study, substrate $\mathrm{pH}$ decreased from 5.55 to about 5.20 immediately following full treatment with both $\mathrm{ZnSO}_{4}$ and $\mathrm{MnSO}_{4}$ (Fig. 2A), but plant cultivation for four weeks resulted in further substrate acidification (Fig. 2B). Theoretically, soil acidification below 5.5 could greatly affect availability of many metal cations (Blaylock and Hunag,
2000). However, effect of $\mathrm{Zn}$ and $\mathrm{Mn}$ treatment on accumulation of $\mathrm{K}, \mathrm{Ca}$ and $\mathrm{Mg}$ in plant tissues was only negligible and seemed to be related rather to the type of treatment instead of changes in substrate pH (Fig. 14 to 16). However, for $1 \mathrm{~g} \cdot \mathrm{l}^{-1}$ Mn-treated $R$. hydrolapathum plants, leaf $\mathrm{Zn}$ concentration significantly increased (Fig. 13B) as a result in decrease of soil pH to 5.1 (Fig. 2B). The observed development- and organ-related differences in $\mathrm{K}, \mathrm{Ca}$ and $\mathrm{Mg}$ concentration were significantly larger than these caused by $\mathrm{Zn}$ and $\mathrm{Mn}$ treatment. It is reasonable to suggest that the physiological effects under $\mathrm{Zn}$ or Mn treatment were not associated with their interaction with mineral nutrition. In addition, plants can increase soil $\mathrm{pH}$ after exposure to heavy metals, as in the case of Eriophorum angustifolium, further leading to decreased availability of metals (Javed et al., 2013), but this was not the case in the present study.

Among physiological responses, photosynthesis-related characteristics are suggested as being extremely sensitive to suboptimal conditions, reflecting overall physiological state of plants (Baker, 2006). Chlorophyll $a$ fluorescence-related parameters are frequently used for early prediction of unfavourable physiological changes (Kan et al., 2017; Kalaji et al., 2018). In particular, chlorophyll $a$ fluorescence measurements have been used in heavy metal studies (Han et al., 2013; Sghaier et al., 2015; Anjum et al., 2016). Photosynthesis is known to be sensitive to excess $\mathrm{Zn}$, and especially photochemistry of photosystem II is inhibited (Mateos-Naranjo et al., 2008; Han et al., 2013), but chlorophyll concentration in leaves can be either increased due to inhibition of their growth (Jain et al., 2010) or decreased (Peng et al., 2015), obviously depending on plant species and experimental conditions. The present results did not support the usefulness of monitoring changes in chlorophyll concentration or chlorophyll $a$ fluorescence parameters in predicting physiological response of $R$. hydrolapathum plants to excess $\mathrm{Zn}$ and $\mathrm{Mn}$. As the respective analyses were performed on the physiologically most relevant actively photosynthesizing leaf, while metal ions were excluded from young leaves, the lack of significant changes reflected the ability of model species to adapt to increased amount of metals in actively photosynthesising tissues, pointing to an efficient mechanism of ion sequestration in vacuoles (Gupta et al., 2016). The two photosynthesis-related parameters were differentially affected by treatments indicating that the monitored changes were not the result of some common mechanism. All treatments except $0.2 \mathrm{~g} \cdot \mathrm{l}^{-1} \mathrm{Zn}$ had negative effect on leaf chlorophyll concentration 2 and 3 weeks after full treatment (Fig. 10A), but the Performance Index showed only minor effect during this period, except at 0.5 g. $1^{-1} \mathrm{Zn}$ (Fig. 10B).

In conclusion, the most important question remains to be answered, namely, do the results of the present study have any importance for practical phytoremediation? In a soil containing high concentration of $\mathrm{Pb}, \mathrm{Zn}$ and $\mathrm{Cd}$, plants of allied species Rumex crispus accumulated 1340 and 1007 $\mathrm{mg} \cdot \mathrm{kg}^{-1} \mathrm{Zn}$ in shoots and roots, respectively (Zhuang et al., 2007). For comparison, the typical $\mathrm{Zn}$ hyperaccumulator 
Sedum alfredii accumulated $6279 \mathrm{mg} \cdot \mathrm{kg}^{-1} \mathrm{Zn}$ in leaves in the same conditions. It was estimated that due to high biomass of $R$. crispus $\left(20 \mathrm{t} \cdot \mathrm{ha}^{-1}\right)$, these plants have good phytoextraction potential in comparison to $S$. alfredii $(5.5 \mathrm{t}$ $\mathrm{ha}^{-1}$ ), leading to removal of $26.8 \mathrm{~kg} \mathrm{Zn}$ per hectare (in comparison, $32.7 \mathrm{~kg} \mathrm{Zn}$ for $S$. alfredii). In the present study, $R$. hydrolapathum plants accumulated up to $1840 \mathrm{mg} \cdot \mathrm{kg}^{-1} \mathrm{Zn}$ and $6400 \mathrm{mg} \cdot \mathrm{kg}^{-1} \mathrm{Mn}$ in leaves, which, together with a high growth rate and biomass at least comparable to that of $R$. crispus, characterises $R$. hydrolapathum as a very promising model species for further studies for practical phytoremediation needs.

\section{ACKNOWLEDGMENTS}

The present study was supported in part by the University of Latvia Effective collaboration projects programme. The described results are part of the Bachelor thesis in biology by Elinna Dišlere. The authors declare that they have no conflict of interest.

\section{REFERENCES}

Albert, R. (1975). Salt regulation in halophytes. Oecologia, 21, 57-71.

Anjum, N. A., Duarte, B., Caēador, I., Sleimi, N., Duarte, A. C., Pereira, E. (2016). Biophysical and biochemical markers of metal/metalloid impacts in salt marsh halophytes and their implications. Front. Environ. Sci., 4, 24.

Anjum, N. A., Singh, H. P., Khan, M. I. R., Masood, A., Per, T. S., Negi, A., Batish, D. R., Khan, N. A., Duarte, A. C., Pereira, E., Ahmad, I. (2015). Too much is bad - an appraisal of phytotoxicity of elevated plant beneficial heavy metal ions. Environ. Sci. Pollut. Res., 22, 3361-3382.

Baker, A. J. M., Brooks, R. R. (1989). Terrestrial higher plants which hyperaccumulate metallic elements - a review of their distribution, ecology and phytochemistry. Biorecovery, 1, 81-126.

Baker, N. R. (2006). A possible role for photosystem II in environmental perturbations of photosynthesis. Physiol. Plant., 81, 563-570.

Blaylock, M. J., Huang, J. W. (2000). Phytoextraction of metals. In: Raskin, I., Ensley, B. D. (eds.). Phytoremediation of Toxic Metals - Using Plants to Clean-up the Environment. Wiley, New York, pp. 53-70.

Bonanno, G., Vymazal, J., Cirelli, G. L. (2018). Translocation, accumulation and bioindication of trace elements in wetland plants. Sci. Total Environ., 631/632, 252-261.

Bothe, H., Słomka, A. (2017). Divergent biology of facultative heavy metal plants. J. Plant Physiol., 219, 45-61.

Boyd, R. S. (2004). Ecology of metal hyperaccumulation. New Phytol., 162, 563-567.

Broadhurst, C. L., Chaney, R. L., Davis, A. P., Cox, A., Kumar, K,, Reeves, R. D., Green, C. E. (2015). Growth and cadmium phytoextraction by Swiss chard, maize, rice, Noccaea caerulescens, and Alyssum murale in $\mathrm{pH}$ adjusted biosolids amended soils. Int. J. Phytoremed., 17, 25-39.

Broadley, M. R., White, P. J., Hammond, J. P., Zelko, I., Lux, A. (2007). Zinc in plants. New Phytol., 173, 677-702.

Buscaroli, A. (2017). An overview of indexes to evaluate terrestrial plants for phytoremediation purposes (Review). Ecol. Indic., 82, 367-380.

Capra, G. F., Coppola, E., Odierna, P., Grilli, E., Vacca, S., Buondonno, A. (2014). Occurrence and distribution of key potentially toxic elements (PTEs) in agricultural soils: A paradigmatic case study in an area affected by illegal landfills. J. Geochem. Explor., 14, 169-180.

Clairmont, K. B., Hagar, W. G., Davis, E. A. (1986). Manganese toxicity to chlorophyll synthesis in tobacco callus. Plant. Physiol., 80, 291-293
Elamin, O. M., Wilcox, G. E. (1986). Effect of magnesium and manganese nutrition on muskmelon growth and manganese toxicity. J. Amer. Soc. Hortic. Sci., 111, 582-587.

Gao, W., Du, Y., Gao, S., Ingels, J., Wang, D. (2016). Heavy metal accumulation reflecting natural sedimentary processes and anthropogenic activities in two contrasting coastal wetland ecosystems, eastern China. J. Soils Sedim., 16, 1093-1108.

Guala, S. D., Vega, F. A., Covelo, E. F. (2011). Development of a model to select plants with optimum metal phytoextraction potential. Environ. Sci. Pollut. Res., 18, 997-1003.

Gupta, N., Ram, H., Kumar, G. (2016). Mechanism of Zn absorbtion in plants: Uptake, transport, translocation and accumulation. Rev. Environ. Sci. Biotechnol., 15, 89-109.

Hacisalihoglu, G., Kochian, L. V. (2003). How do some plants tolerate low levels of soil $\mathrm{Zn}$ ? Mechanisms of zinc efficency in crop plants. New Phytol., 159, 341-350.

Hamed, K. B., Ellouzi, H., Talbi, O. Z., Hessini, K., Slama, I., Ghnaya, T., Bosch, S. M., Savoure, A., Abdelly, C. (2013). Physiological response of halophytes to multiple stresses. Funct. Plant Biol., 40, 883-896.

Han, R., Quinet, M., André, E., van Elteren, J. T., Destrebecq, F., Vogel-Mikuš, K., Cui, G., Debeljak, M., Lefčvre, I., Lutts, S. (2013). Accumulation and distribution of $\mathrm{Zn}$ in the shoots and reproductive structures of the halophyte plant species Kosteletzkya virginica as a function of salinity. Planta 238, 441-457.

Jain, R., Srivastava, S., Solomon, S., Shrivastava, A. K., Chandra, A. (2010). Impact of excess zinc on growth parameters, cell division, nutrient accumulation, photosynthetic pigments and oxidative stress of sugarcane (Saccharum spp.). Acta Physiol. Plant., 32, 979-986.

Javed, M. T., Stoltz, E., Lindberg, S., Greger, M. (2013). Changes in pH and organic acids in mucilage of Eriophorum angustifolium roots after exposure to elevated concentrations of toxic elements. Environ. Sci. Pollut. Res., 20, 1876-1880.

Jin, X. F., Yang, X. E., Islam, E., Liu, D., Mahmood, Q., Li, H., Li, J. (2008). Ultrastructural changes, zinc hyperaccumulation and its relation with antioxidants in two ecotypes of Sedum alfredii Hance. Plant Physiol. Biochem. 46, 997-1006.

Kalaji, H. M., Račková, L., Paganová, V., Swoczyna, T., Rusinowski, S., Sitko, K. (2018). Can chlorophyll- $a$ fluorescence parameters be used as bio-indicators to distinguish between drought and salinity stress in Tilia cordata Mill? Environ. Exp. Bot., 152, 149-157.

Kan, X., Ren, J., Chen, T., Cui, M., Li, C., Zhou, R., Zhang, Y., Liu, H., Dexiang, D., Yin, Z. (2017). Effects of salinity on photosynthesis in maize probed by prompt fluorescence, delayed fluorescence and P700 signals. Environ. Exp. Bot., 140, 56-64.

Küpper, H., Zhao, F. J., McGrath, S. P. (1999). Cellular compartmentation of zinc in leaves of the hyperaccumulator Thlaspi caerulescens. Plant Physiol., 119, 305-311.

Li, Q., Chen, L.-S., Jiang, H.-X., Tang, N., Yang, L.-T., Lin, Z.-H., Li, Y., Yang, G.-H. (2010). Effects of manganese-excess on $\mathrm{CO}_{2}$ assimilation, ribulose-1,5-bisphosphate carboxylase/oxygenase, carbohydrates and photosynthetic electron transport of leaves, and antioxidant systems of leaves and roots in Citrus grandis seedlings. BMC Plant Biol., 10, 42.

Li, T.-Q., Yang, Z. E., Yang, J.-Y., He, Z.-L. (2006). Zn accumulation and subcellular distribution in the $\mathrm{Zn}$ hyperaccumulator Sedum alfredii Hance. Pedosphere, 16, 616-623.

Liang, H. M., Lin, T. H., Chiou, J. M., Yeh, K. C. (2009). Model evaluation of the phytoextraction potential of heavy metal hyperaccumulators and non-hyperaccumulators. Environ. Pollut., 157, 1945-1952.

Liang, L., Liu, W., Sun, Y., Huo, X., Li, S., Zhou, Q. (2017). Phytoremediation of heavy metal contaminated saline soils using halophytes: Current progress and future perspectives. Environ. Res., 25, 269-281.

Liu, J., Shang, W., Zhang, Zhu, Y., Yu, K. (2014). Mn accumulation and tolerance in Celosia argentea Linn.: A new Mn-hyperaccumulating plant species. J. Hazard. Mater., 267, 136-141. 
Liu, P., Tang, X., Gong, C., Xu, G. D. (2010). Manganese tolerance and accumulation in six Mn hyperaccumulators or accumulators. Plant Soil, 335, 285-395.

Loneragan, J. F. (1988). Distribution and movement of manganese in plants. In: Graham, R. D., Hannam, R. J., Uren, N. C. (eds.). Manganese in Soils and Plants. Developments in Plant and Soil Sciences, Vol 33. Springer, Dordrecht, pp. 113-124.

Longnecker, N. E., Robson, A. D. (1993). Distribution and transport of zinc in plants. In: Robson, A. D. (ed.). Zinc in Soils and Plants. Developments in Plant and Soil Sciences, Vol 55. Springer, Dordrecht, pp. 79-91.

Lutts, S., Levčvre, I. (2015). How can we take advantage of halophyte properties to cope with heavy metal toxicity in salt-affected areas. Ann. Bot., 115, 509-528

Masarovičová, E., Králová, K., Kummerová, M. (2010). Principles of classification of medicinal plants as hyperaccumulators or excluders. Acta Physiol. Plant., 32, 823-829.

Mateos-Naranjo, E., Redondo-Gómez, S., Cambrollé, J., Luque, T., Fugeroa, M. E. (2008). Growth and photosynthetic responses to zinc stress of an invasive cordgrass Spartina densiflora. Plant Biol., 10, 754-762.

Mitchell, R. G., Spliethoff, H. M., Ribaudo, L. N., Lopp, D. M., Shayler, H. A., Marquez-Bravo, L. G., Lambert, V. T., Ferenz, G. S., Russell-Anelli, J. M., Stone, E. B., McBride, M. B. (2014). Lead (Pb) and other metals in New York City community garden soils: Factors influencing contaminant distributions. Environ. Pollut., 187, 162-169.

Moray, C., Goolsbay, E. W., Bromham, L. (2016). The phylogenetic association between salt tolerance and heavy metal hyperaccumulation in Angiosperms. Evol. Biol., 43, 119-130.

Naidu, R., Oliver, D., McConnell, S. (2003). Heavy metal phytotoxicity in soils. In: Proceedings of the Fifth National Workshop on the Assessment of Site Contamination. Environment Protection \& Heritage Council, Adelaide, pp. 235-241.

Osvalde, A. (2011). Optimization of plant mineral nutrition revisited: The roles of plant requirements, nutrient interactions, and soil properties in fertilization management. Environ. Exp. Biol., 9, 1-8.

Peng, D., Shafi, M., Wang, Y., Li, S., Yan, W., Chen, J., Ye, Z., Liu, D. (2015). Effect of $\mathrm{Zn}$ stresses on physiology, growth, $\mathrm{Zn}$ accumulation, and chlorophyll of Phyllostachys pubescens. Environ. Sci. Pollut. Res., 22, 14983-14992.

Pinto, E., Aguiar, A. R. M., Ferreura I. M. P. L. V. O. (2014). Influence of soil chemistry and plant physiology in the phytoremediation of $\mathrm{Cu}$, Man, and Zn. Crit. Rev. Plant Sci., 33, 351-373.

Rascio, N., Navari-Izzo, F. (2011). Heavy metal hyperaccumulating plants: How and why do they do it? And what makes them so interesting? Plant Sci., 180, 169-181.

Reeves, R. D., van der Ent, A., Baker, A. J. M. (2018). Global distribution and ecology of hyperaccumulator plants. In: van der Ent, A., Echevarria, G., Baker, A., Morel, J. (eds.). Agromining: Farming for Metals. Mineral Resource Reviews. Springer International Publishing, Cham, pp. 75-92.

Reeves, R. D., Baker, A. J. M., Jaffré, T., Erskine, P. D., Echevarria, G., van der Ent, A. (2017). A global database for plants that hyperaccumulate metal and metalloid trace elements. New Phytol., 218, 407-411.

Reichman, S. (2002). The Responses of Plant to Metal Ttoxicity: A Review Focusing on Copper, Manganese and Zinc. Australian Minerals \& Energy Environment Foundation, Melbourne. 54 pp.

Ren, F., Liu, T., Liu, H., Hu, B. (1993). Influence of zinc on the growth, distribution of elements, and metabolism of one-year old American ginseng plants. J. Plant Nutr., 16, 393-405.

Samsone, I., Ievinsh, G. (2018). Different plant species accumulate various concentration of $\mathrm{Na}^{+}$in a sea-affected coastal wetland during a vegetation season. Environ. Exp. Biol., 16, 117-127.
Santos, E. F., Santini, J. M. K., Paixćo, A. P., Jśnior, E. F., Lavres, J., Campos, M., dos Reis, A. R. (2017). Physiological highlights of manganese toxicity symptoms in soybean plants: Mn toxicity responses. Plant Physiol. Biochem., 113, 6-19.

Sghaier, D. B., Duarte, B., Bankaji, I., Caēador, I., Sleimi, N. (2015). Growth, chlorophyll fluorescence and mineral nutrition in the halophyte Tamarix gallica cultivated in combined stress conditions: Arsenic and NaCl. J. Photochem. Photobiol. B Biol., 149, 204-214.

Shen, Z. G., Zhao, F. J., McGrath, S. P. (1997). Uptake and transport of zinc in the hyperaccumulator Thlaspi caerulescens and the non-hyperaccumulator Thlaspi ochroleucum. Plant Cell Environ., 20, 898-906.

Sruthi, P., Shackira, A. M., Puthur, J. T. (2017). Heavy metal detoxification mechanisms in halophytes: An overview. Wetlands Ecol. Manag., 25, 129-148.

Strasser, R. J., Srivastava, A., Tsimilli-Michael, M. (2000). The fluorescence transient as a tool to characterise and screen photosynthetic samples. In: Yunus, M., Pathre, U., Mohanty, P. (eds.). Probing Photosynthesis: Mechanisms, Regulation and Adaptation. Taylor \& Francis, London, pp. 445-483

Tang, S., Fang, Y. (2012). Copper accumulation by Polygonum microcephalum D. Don and Rumex hastatus D. Don from copper mine spoils in Yunnan Province, P. R. China. Environ. Geol., 40, 902-907.

Tang, Y.-T., Qiu, R.-L., Zeng, X-.W., Ying, R.-R., Yu, F.-M., Zhou, X.-Y. (2009). Lead, zinc, cadmium hyperaccumulation and growth stimulation in Arabis paniculata Franch. Environ. Exp. Bot., 66, 126-134.

Van Oosten, M. J., Maggio, A. (2015). Functional biology of halophytes in the phytoremediation of heavy metal contaminated soils. Environ. Exp. Bot., 111, 135-146.

Visioli, G., Marmiroli, N. (2013). The proteomics of heavy metal hyperaccumulation in plants. J. Proteom., 79, 133-145.

Vondráčková, S., Hejcman, M., Száková, J., Müllerová, V., Tlustoš, P. (2014). Soil chemical properties affect the concentration of elements (N, P $\mathrm{K}, \mathrm{Ca}, \mathrm{Mg}, \mathrm{As}, \mathrm{Cd}, \mathrm{Cr}, \mathrm{Cu}, \mathrm{Fe}, \mathrm{Mn}, \mathrm{Ni}, \mathrm{Pb}$, and $\mathrm{Zn}$ ) and their distribution between organs of Rumex obtusifolius. Plant Soil, 379, 231-245.

Vondráčková, S., Száková, J., Drábek, O., Tejnecký, V., Hejcman, M., Müllerová, V., Tlustoš, P. (2015). Aluminium uptake and translocation in Al hyperaccumulator Rumex obtusifolius is affected by low-molecular weight organic acids content and soil pH. PLOS One, 10, e0123351.

Wang, A. S., Angle, J. S., Rufus, L. C., Delorme, T. A., Reeves, R. D. (2006) Soil $\mathrm{pH}$ effects on uptake of $\mathrm{Cd}$ and $\mathrm{Zn}$ by Thlaspi caerulencens. Plant Soil, 281, 325-337.

Wang, C., Zhang, S. H., Wang, P. F., Hou, J., Zhang, W. J., Li ,W., Lin, Z. P. (2009). The effect of excess $\mathrm{Zn}$ on mineral nutrition and antioxidative response in rapeseed seedlings. Chemosphere, 75, 1468-1476.

Xue, S. G., Chen, Y. X., Reeves, R. D., Baker, A. J. M., Lin, Q., Fernando, D R. (2004). Manganese uptake and accumulation by the hyperaccumulator plant Phytolacca acinosa Roxb. (Phytolaccaceae). Environ. Pollut., 131, 393-399.

Yang, J., Ye, Z. (2009). Metal accumulation and tolerance in wetland plants. Front. Biol. China, 4, 282-288.

Yang, W., Li, H., Zhang, T., Sen, L., Ni, W. (2014). Classification and identification of metal-accumulating plant species by cluster analysis. Environ. Sci. Pollut. Res., 21, 10626-10637.

Ye, M., Liao, B., Li, J. T., Mengoni, A., Hu, M., Luo, W. C., Shu, W. S. (2012). Contrasting patterns of genetic divergence in two sympatric pseudo-metallophytes: Rumex acetosa L. and Commelina communis L. BMC Evol. Biol., 12, 84.

Zhuang, P., Wang, Q. W., Wang, H. B., Shu, W. S. (2007). Phytoextraction of heavy metals by eight plant species in field. Water Air Soil Pollut., 184, $235-242$. 

Zn UN Mn KONCENTRĀCIJU SUBSTRĀTĀ

Šì pētījuma mērkisis bija noskaidrot, vai Rumex hydrolapathum Huds indivīdi no sāḷā mitrāja spēj paciest biogēno smago metālu Zn un Mn augstas koncentrācijas klātbūtni substrātā un uzkrāt šos metālus virszemes dạās. Augu fizioloǵisko stāakokli noteica, izmantojot nedestruktīvu hlorofila un hlorofila $a$ fluorescences analīzi. $R$. hydrolapathum augi uzkrāja līdz $1840 \mathrm{mg} \cdot \mathrm{kg}^{-1} \mathrm{Zn} \mathrm{un} 6400 \mathrm{mg} \cdot \mathrm{kg}^{-1} \mathrm{Mn}$ vecajās lapās. Hlorofila koncentrācija un hlorofila a fluorescences parametri nebija izmantojami $R$. hydrolapathum augu fizioloğiskās reakcijas paredzēšanai uz $\mathrm{Zn}$ un $\mathrm{Mn}$ pārbagātību, jo to būtisku izmaiṇu neesamība atspoguḷoja modeḷsugas spēju pielāgoties metālu palielinātam daudzumam aktīvi fotosintezējošos audos. $R$. hydrolapathum augu izturība pret $\mathrm{Zn}$ un Mn parādās fizioloğiskā līmenī, ierobežojot metālu uzkrāšanos jaunākajās lapās un saknēs un veicinot gan jaunu lapu attīstību, gan lielāko daḷu Zn un Mn uzkrājošo vecāko lapu novecošanos. $R$. hydrolapathum var raksturot kā perspektīvu modeḷsugu turpmākiem praktiskās fitoremediācijas pētījumiem. 